\title{
The Application of Modified Gasing Game to Improve the Elementary School Students' Vocabulary in Singkawang Tourism Site, West Kalimantan
}

\author{
Ufi Ruhama', Iin Maulina² \\ 1ufiruhama@unmuhpnk.ac.id \\ 1,2Universitas Muhammadiyah Pontianak
}

\begin{abstract}
This Classroom Action Research was aimed at knowing whether the implementation of modified gasing game was effective in improving students' vocabulary mastery. The population in this study was the students of Muhammadiyah 2 Singkawang Elementary School with a total sample of 25 students by using a random sampling technique. The Classroom Action Research objectives were to describe the use of a modifiedgasing game on vocabulary, to investigate the Muhammadiyah 2 Singkawang Elementary School fourth grade students' vocabulary mastery and to identify the improvement of the Elementary School fourth grade students' vocabulary mastery using a modified-gasing game. It employed three cycles with four stages (planning, action, observation, and reflection). In each cycle, the data were analyzed to find out the increase in students' vocabulary. The researcher used the observation, test and documentation in collecting the data. The results of the research indicated that the implementation of gasing game was merely effective in improving the students' vocabulary in terms of numerical grade scores. The results showed the improvement in each cycle as in the first cycle by 0 percent, in the second cycle by 48 percent, and in the third cycle by 96 percent which are categorized very good. The results concluded that this modified-gasing game can improve the Muhammadiyah 2 Singkawang Elementary School fourth grade students' vocabulary significantly in the aspects of word guessing.
\end{abstract}

Keywords: Vocabulary, Traditional game, Gasing

\section{INTRODUCTION}

School is meant to be a comfortable and enjoyable place for students to develop their intelligence and morals (Bucholz \& Sheffler, 2009; Diah, etal., 2017). In developing student's intelligence, the learning quality in the classroom needs to be constantly improved. This leaves homework for the teachers to increase their professionalism and creativity. The quality of learning in schools is shown from how the learning atmosphere can support an interesting, challenging, fun, and valuable learning process for the development of educational professionalism (Mardapi, 2008). Teacher as the main agent in the teaching-learning process in class is expected to be able to create a fun and attracting learning atmosphere particularly at elementary level. 
Elementary school age is the phase when students encounter rapid development, comprehend a lesson easier, and become an active learner (Suyanto, 2006). Nonetheless, English subjects at elementary school have their own complexity. Students experience various problems in learning English at elementary school. The problems are found at learning the four skills of language; namely listening, speaking, reading, and writing. The enabling skills, e.g. pronunciation and vocabulary mastery, cause problems for students as well. To be able to communicate well, students should master an adequate amount of vocabulary and know how to use it properly (Huyen \& Nga, 2008). Vocabulary mastery is one of the most frequently encountered difficulties in teaching English at the elementary school level. The majority of students find it difficult and boring to memorize vocabulary by reading textbooks. An interesting and enjoyable learning strategy is needed to overcome this problem (Mafulah, $2015: 3-4$ ). Game is one of the appropriate learning strategies to use.

Learning will be valuable for children's cognitive development particularly if associated with the customs moreover culture. Games and songs provide the customs and cultural value (Nyota \& Mapara, 2008). The current learning process can be integrated into traditional culture, like traditional games that have various benefits, to enable the learning process to be more fun and enjoyable (Majoni \& Chinyanganya, 2014). Game based learning scenarios engage learners to be interactive, problem-solving situations which encourage critical thinking, communication, collaboration, and adaptability for functional knowledge acquisition (Trajkovik, 2018). In addition the game players are usually highly motivated to encourage in the gaming activities driven by the story or goal behind, interactivity and possibility to enhance performance through repetition. Each country has its traditional games, which can be used for educational aims, while the integration of these games will shift the pedagogical approach from teacher centered to student centered atmosphere. Gil Madrona et al (2014) said that using games in physical education in primary education is very crucial. The use of traditional games can enhance students' social skills.

The Singkawang city is one of the tourist destinations in West Kalimantan Province. Located in the hilly and coastal area provides the city many places with beautiful views. Pasir Panjang Beach, Sinka Zoo, Sinka Island Park, Bougenville Park Hill, Teratai Indah Park, and Blue Lake are some of the tourism sites in Singkawang. Day by day, the city 
grows popular for its tourism spots making more and more local and foreign tourists come to visit the city. The visit reaches its peak on holidays.

The local people's ability in communicating English supports the city as a tourism destination. School offers the most effective opportunity to help local people improve their English language knowledge. However, students at elementary school in Singkawang experience difficulties in learning English due to an ineffective learning process. This, in turns, affects students' ability to understand the subject well.

The fact leads to the necessity to learn English earlier in Singkawang. English learning experience should give students an enjoyable learning experience. Learning delivered with games will increase children's enthusiasm and motivation. The increasingly sophisticated technology causes people to, slowly, leave the traditional culture. The learning process integrated with traditional culture offers a more fun learning process as shown from traditional games which have many benefits (Majoni \& Chinyanganya, 2014). Gasing is one of the games once popular among the people of Singkawang which now loses its popularity by the course of time. The introduction of traditional games was very effective to stimulate students' cognitive and motoric skills. This will improve their vocabulary mastery as well as to revive the local culture of gasing game. The teaching learning process in Muhammadiyah 2 Singkawang Elementary school was still monotonous that made the students bored while studying. The objective of this study was to describe and to identify the improvement of the Muhammadiyah 2 Singkawang Elementary School in the fourth grade students' vocabulary mastery using a modifiedgasing game showed that this game was able to improve the students' vocabulary significantly.

\section{RESEARCH METHOD}

This research employed the Classroom Action Research model of Kemis and Mc Taggart and applied two cycles with four stages (planning, action, observation, and reflection) in each cycle. The population in this study was the Muhammadiyah 2 Singkawang Elementary School fourth grade students with a total sample of 25 students taken using a random sampling technique.

Classroom Action Research is a systematic method done by the teacher and administrator, the main focus on collecting information about the teaching learning process (Mills in Mertler, 2009: 4). The purpose is to identify the situations from the 
research object and do the changes in its application. Classroom Action Research is an important method for changing and enhancing in certain education (Cohen, Manion, Marrison, 2000: 226).

The researcher used interviews and observation sheets to identify students' interest and activeness during the learning process using a modified-gasing game. The interview guide sheet was used to collect complementary data to determine students' perceptions on the difficulties encountered while learning vocabulary.

Playing gasing is very easy and simple. However, the game needs to be adjusted to meet the research needs of improving students' vocabulary mastery. For this reason, the modification of the game is as follows:

a. Students were divided into six groups with five students each. Each group had gasings with different colors; red, yellow, green, blue, and brown.

b. Students played the gasing with their group members. Groups were named Group 1, Group 2, Group 3, Group 4, Group 5, and Group 6.

c. The game was held in a school yard or a wide field.

d. Students held the gasing with their left hand while their right hand held the string. Then, the students winded or wrapped it with the string from the bottom to the body of the gasing by applying enough force while rotating the gasing.

e. On the count of three, the students threw their gasing to the ground.

f. Once it touched the ground, it would rotate randomly for a moment and became stable after finding its equilibrium and continued to spin. The spin then started to slow as the angular momentum and the gyroscopic effect decreased. Until finally, the gasing fell to the ground.

g. The student whose gasing spun the longest and who was able to articulate vocabulary the most was the winner.

h. The winner in each group would play against each other until reaching the top five in the final.

\section{RESULTS AND FINDINGS}

This classroom action research was carried out for six meetings divided into three cycles. Each cycle took two meetings of 35 minutes. Planning, action, observation, and reflection stages were applied to this research. The researchers teamed up with 
collaborators to determine the schedule to implement the cycle. In each meeting, learning activities consisted of introduction, main activities, and closing activities.

In the first meeting, the researcher opened the class by giving the students openended questions and brainstorming on the topic taught. The teacher explained the topic of the family to the students and introduced several vocabularies related to the topic. It is found that the students encountered difficulties in finding correct vocabulary as the English subject was not optimally taught. It has been offered only as an extracurricular course. Closing the class, the teacher provided conclusions on the topic taught.

In the second cycle, the teacher applied the gasing game in the classroom. The students learned very enthusiastically. The topic taught was still the same to the first cycle, the family. The teacher divided the students into several groups to play gasing. The students were asked to articulate the vocabulary on the topic while playing. When the gasing started to spin, the student started to articulate the vocabulary they already learned one by one. The student who was able to articulate the most vocabulary while the gasing was spinning became the winner.

In the third cycle, the topic taught was still the same. However, the vocabulary taught was enriched. The students were still divided into groups and given the chance to play. The game brought an enjoyable learning atmosphere to the students as they love playing.

The quantitative data in the first cycle, the aspects were word guessing, synonyms and antonyms, and pronunciation. It can be seen as follows:

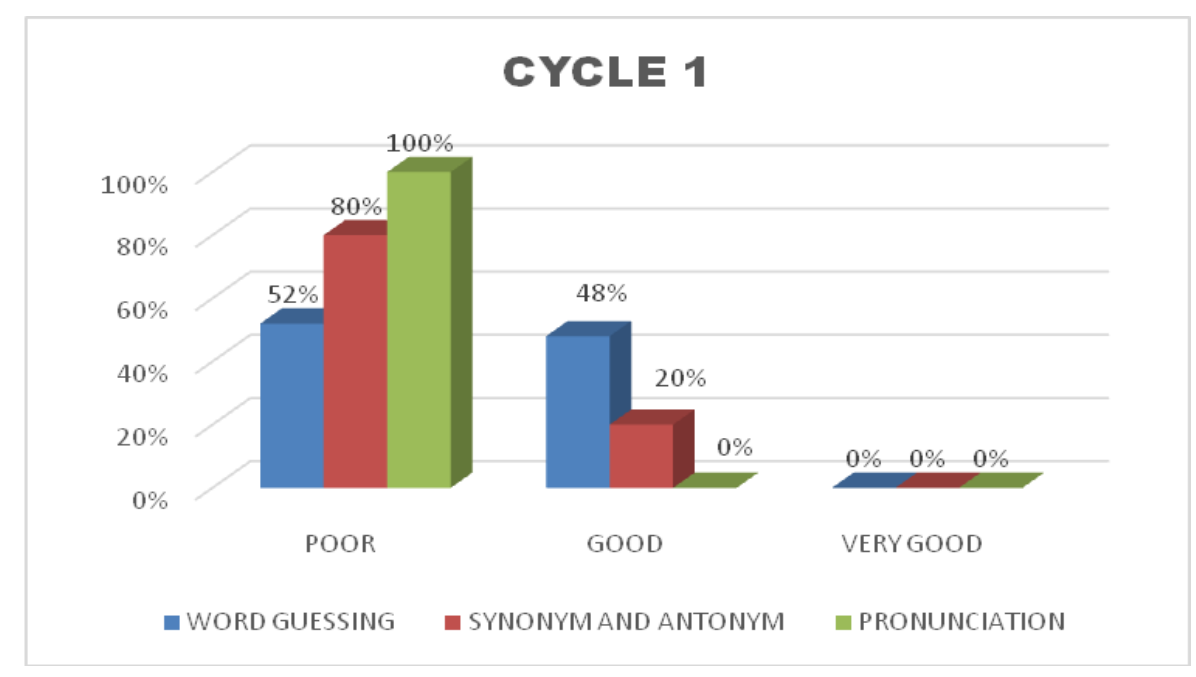

Figure 1. The Presentage of Cycle 1

In the figure 1, the first cycle showed a dissatisfying result as English is not a compulsory subject at Muhammadiyah 2 Singkawang Elementary School. The sample of 
this research happened not to learn the topic ever before. The result showed that in the criteria of word guessing, it still has $52 \%$ students in the poor category, $48 \%$ students in the good category, and no one student got very good in this section. As for synonyms and antonyms mastery, $80 \%$ students which are categorized poor and only $20 \%$ student reached good, but all the students got poor in pronunciation mastery.

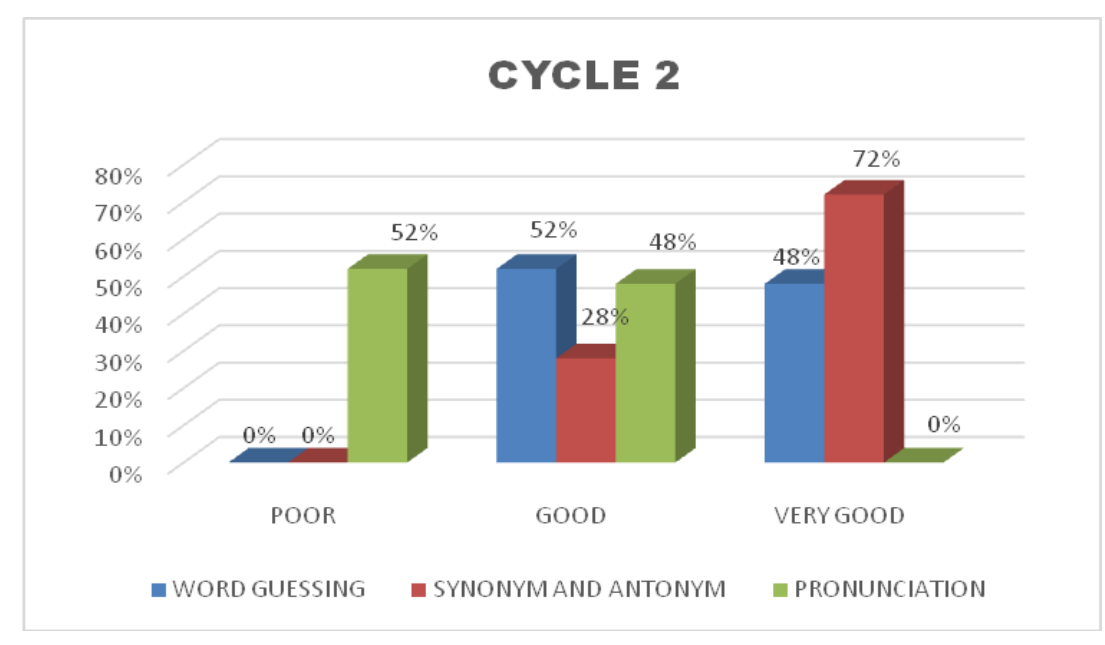

Figure 2. The Presentage of Cycle 2

In the second cycle, the students looked enthusiastic and motivated in learning. The students seemed to be more proficient in playing the gasing while articulating vocabularies. Based on the figure 2 above, the result showed that $0 \%$ of students got poor in the aspects of word guessing, even in pronunciation. Meanwhile, there were $52 \%$ poor in pronunciation, and $48 \%$ good in pronunciation. Furthermore, the antonym mastery also found an improvement by $72 \%$ which is categorized very good in the aspect of synonyms and antonyms. The fact suggested that more exposure on the topic is needed. This is due to the first encounter of basic vocabulary on family members the students experienced.

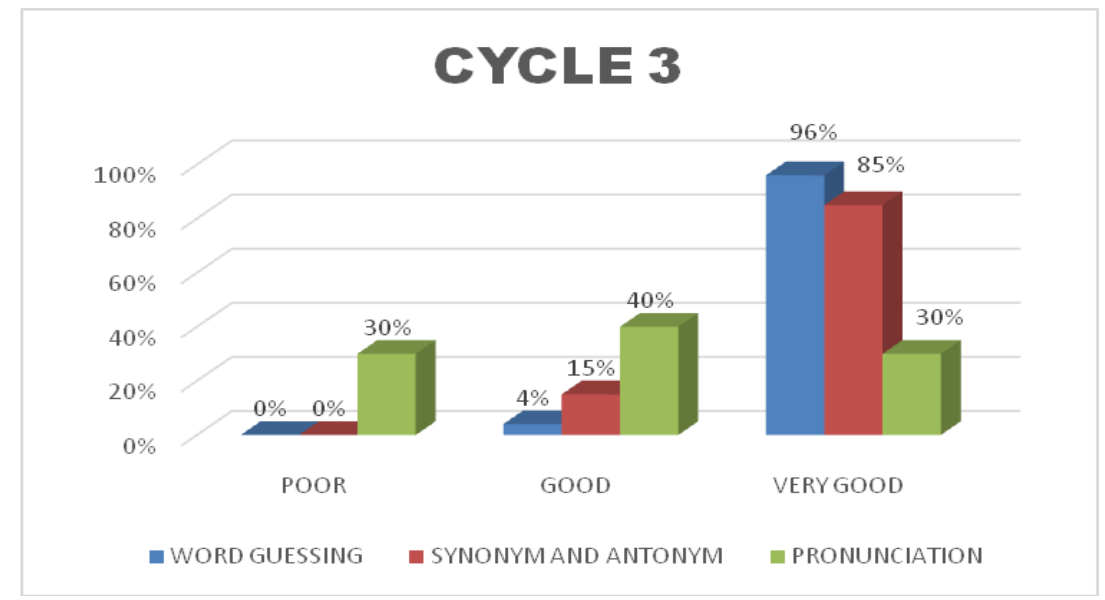

Figure 3. The Presentage of Cycle 3 
From the figure in the third cycle above, the students were very enthusiastic in learning while playing. Competition heated as they kept trying to win the game with their group. Significant improvement was seen in this cycle. Word guessing mastery reached very good by $96 \%$ and synonyms antonyms mastery scored $85 \%$ on very good category. Besides, pronunciation mastery increased with the very good category by $30 \%$, although there were $30 \%$ still in the poor category.

\section{CONCLUSION}

Learning English will be very interesting if the teacher can deliver methods that suit students' interest. As children love to play, integrating games into class should be a priority. The pre-observation phase indicated that most students did not have a good vocabulary mastery. Therefore, the use of gasing game as learning media is relevant to overcome this problem at the elementary school. The implementation of the gasing game in class through the three cycles of teaching-learning process has helped improve the students' vocabulary mastery, particularly in the fourth grade students in Muhammadiyah 2 Elementary School Singkawang. The mistakes on the aspects of word guessing, synonym and antonym, and pronunciation were able to be minimized. The classroom action research is found adaptive to minimize the existing problems as it is conducted through cycles which consist of planning, action, observation, and reflecting stages.

From the results, the conclusion can be drawn as follows:

a. It is not only able to improve students' vocabulary mastery, the implementation of traditional games of gasing can contribute to students' positive response in learning. The students felt learning integrated with playing gasing game to be comfortable and enjoyable.

b. The three-cycle applied in this method indicated that it met the objective of this study was to identify the improvement of the Elementary School, fourth grade students' vocabulary mastery using a gasing game. This was shown from the score achieved in the third cycle where the average score improved from 0 percent in the first cycle to 96 percent in the third cycle in the very good category, particularly the aspects of word guessing.

c. The implementation of gasing game can also train students' psychomotor and ability to cooperate. Besides, this game can preserve the culture and traditional games, particularly in Singkawang, West Kalimantan. 


\section{ACKNOWLEDGEMENTS}

This research was fully funded and supported by the Ministry of Research Technology and Higher Education of the Republic of Indonesia so that I would like to extend my foremost and sincere gratitude to the Ministry of Research Technology and Higher Education for the grant and fund. My gratitude also goes to the headmaster, teachers, and students of SD Muhammadiyah 2 Singkawang for permitting the use of the research site and facilities and for their contribution throughout the completion of this work. My completion of this research could not have been accomplished without the support of Universitas Muhammadiyah Pontianak particularly to Research and Community Services Institute (LPPM). Finally, I would like to acknowledge everyone who played a role in this research, each of them has provided advice, and suggestions during the research process. Thank you all for your unwavering encouragement.

\section{REFERENCES}

Bucholz, J.L \&Sheffler, J.L. (2009). Creating a warm and inclusive classroom enviroment: planning for all children to feel welcome. Journal for Inclusive Education, Vol.2 No.4. Retrieved from: corescholar@www.libraries.wright.edu.

Cohen, Louis, dkk. (2000). Research Methods in Education. London;: RoutledgeFalmers.

Diah, A. (2017). Psikologi perkembangan anak usia dini. Yogyakarta: Pustaka Pelajar.

Gil Madrona, P., Samalot-Rivera, A., Cristina Gutiérrez Marín, E., Rodenas-Jiménez, J., \& Rodenas-Jiménez, M. L. (2014). Improving Social Skills through Physical Education in Elementary 4th Year. American Journal of Sports Science and Medicine, 2(6A), 5-8. https://doi.org/10.12691/ajssm-26A-2

Huyen, N. T. T \&Nga, K. T. T. (2008). Learning vocabulary through games. Asian EFL Journal, Vol.5, No.4: 90-105.

Mafulah, S. (2015). Permainan tradisional pada pembelajaran kosakata bahasa inggris di SDN Banjarejo 01. Jurnal Vokasi Universitas Brawijaya. Retrieved from: vokasindo.ub.ac.id,

Majoni, C \& Chinyangana, T.L. (2014). Intergrating traditional african education into current educational practices: suggestion for primry school pedagogy. Greener Journal of Education and Training Studies, Vol.2, No.3: 64-70. Retrieved from: http://gjpurnals.org/GJETS/Publication/2014/July.

Mardapi, D. (2003). Desain penilaian dan pembelajaran. Makalah disampaikan pada lokakarya sistem penjaminan mutu proses pembelajaran 19 Juni 2003 di Universitas Gajah Mada. 
Mertler, C.A. (2009). Action Research. Teachers as researchers in the classroom. Second Edition. USA: SAGE Publication.

Nyota, S \& Mapara, J. (2008) Shona traditional games and play: songs as indigeneous way of knowing. Journal of Pan African Studies, Vol.2, No.4.Retrieved from: www.researchgate.net.

Suyanto, K. (2006). English for young learners: melejitkan potensi anak melalui english class yang fun, asyik dan menarik. Jakarta: Bumi Aksara.

Trajkovik V, Malinovski T, VasilevaStojanovskaT, Vasileva M (2018) Traditional games in elementary school: Relationships of student's personality traits, motivation and experience with learning outcomes. PLoS ONE 13 (8): e0202172.https://doi.org/10.1371/journal. pone.0202172 